\title{
Contaminants of Emerging Concern: A Review of Biological and Economic Principles to Guide Water Management Policies
}

\author{
Angels Xabadia ${ }^{1}$, Encarna Esteban ${ }^{2}$, Yolanda Martinez ${ }^{3}$ and \\ Iban Ortuzar ${ }^{1}$ \\ ${ }^{1}$ Department of Economics, University of Girona, Girona, Spain; \\ angels.xabadia@udg.edu \\ ${ }^{2}$ Department of Economic Analysis, School of Social Sciences and \\ Humanities, University of Zaragoza, Teruel, Spain and Institute of \\ Agrifood and Techonology IA2 (University of Zaragoza-CITA), \\ Zaragoza, Spain \\ ${ }^{3}$ Department of Economic Analysis and Institute of Agrifood and \\ Techonology IA2, University of Zaragoza-CITA, Zaragoza, Spain
}

\begin{abstract}
Awareness regarding water contamination has increased recently due to the emergence of a multitude of pollutants that pose a high risk to ecosystems and human health. The huge number and heterogeneity of contaminants of emerging concerns (CECs), in terms of their occurrence, biochemical behavior, and environmental impacts complicate their monitoring and control. This paper reviews empirical literature on the current situation of CECs to analyze how the identification and control of these emissions have been addressed. The results highlight the need for the risks and impacts of these emerging contaminants to be assessed from an integrated perspective, and for accurate estimates of the cost-efficiency of abatement technologies, taking into account potential side effects, to be provided. Thus, there
\end{abstract}


is an urgent need for economic research that provides guidance for regulating these substances. Furthermore, issues such as developing protocols for measuring their presence and eco-toxicity, the way in which they are introduced into the environment, and their potential impact on aquatic ecosystems have yet to be covered.

Keywords: Emerging pollutants (contaminants of emerging concern); biological processes; water quality; ecosystems and human health; water management

JEL Codes: Q25, Q53

\section{Introduction}

Over the last century, intense population growth coupled with strong economic development has triggered an ever-increasing demand for freshwater which has resulted in a serious deterioration of water bodies. Most hydrological water systems, including river basins, aquifers, lagoons, and other aquatic resources, present serious problems of depletion and/or water quality impairment (Koundouri et al., 2017). Thus, protecting and restoring hydrological systems is currently one of the primary environmental challenges worldwide.

Water pollution, identified as one of the main problems of water bodies, reduces economic growth and poses a high risk for human and ecosystem health. The economic literature provides greater insights into the need and relevance of controlling water contamination (Shortle and Horan, 2017). Economic instruments have been proposed as water pollution management mechanisms, especially in the case of pollution caused by high nutrient and pesticide loads from agricultural practices (Goetz and Xabadia, 2015; Iho et al., 2015; Lankoski et al., 2008; Sexton et al., 2007; Shortle, 2017). That said, economic growth has triggered a change in production and consumption patterns towards commodities that are high in chemical substances, for instance, pharmaceuticals, personal-care products (PCPs), chemical products, and plastics, among others. In recent years, emerging pollutants from both point and diffuse pollution sources have been identified in the environment and are 
presenting new challenges for water authorities and economic regulations. The presence of these pollutants in the environment has become a widespread problem in both developed and developing countries around the world (Noguera-Oviedo and Aga, 2016).

While the impacts of many emerging substances are still not completely understood, several studies have already reported the association between these compounds and human health and well-being issues (Bunke et al., 2019; Francisco et al., 2019; Gwenzi et al., 2018; Lei et al., 2015; Schwarzenbach et al., 2006; Snow et al., 2019). Furthermore, environmental damage to habitats and ecosystems has also been described in the literature (Caliman and Gavrilescu, 2009; de Souza Machado et al., 2018; Gwenzi et al., 2018; Kroon et al., 2020; Vasilachi et al., 2021). Moreover, pollution from most of these substances is expected to increase not only due to economic development but also because of climate change (Kattwinkel et al., 2011). However, most of these contaminants are yet to be included in monitoring programs or considered in environmental legislation. Although it is now a matter of record that the type of contamination of water bodies has changed over the past few decades, control mechanisms and regulations have not been updated to address the new challenges.

In addition to the above, yet another problem is the lack of economic literature related to these emerging contaminants. As noted by Remoundou and Koundouri (2009), "There is increasing recognition that linked environment and health impacts require economic assessment in order to receive adequate consideration in policy". Although some studies have been carried out that measure the removal benefits for particular substances (Bellver-Domingo et al., 2018; Molinos-Senante et al., 2013), there is a shortage of studies estimating the monetary values associated with the environmental risks of most of the emerging pollutants. Furthermore, there are very few studies taking into account the economic impact and possible "trade-offs" of improving remediation technologies to mitigate and/or remove these substances from the environment. Therefore, improving our scientific understanding about these substances is paramount to better inform local, regional, and national authorities in the design and correct implementation of policies aimed at controlling pollution levels.

This review aims to examine and summarize developments and the progress made to date in the research of emerging contaminants 
in order to identify the areas where further economic analyses are needed. Based on this purpose, we performed a search in the Web of Science and Scopus of papers on emerging contaminants, contaminants of emerging concerns (CECs), and new pollutants; especially in the areas of water resources and business economics. Articles retrieved from the searches were screened by title and abstract to establish those that might be suitable for an in-depth analysis. Because of the lack of economic studies, to increase the number of articles suitable for analysis we also used some "snowballing" techniques such as following up reference lists of selected articles and direct searches in the relevant economic journals. Finally, in order to include information regarding the legal and regulatory framework for these contaminants, we also analyzed national and international law and reports that regulate the use, incidence, and/or control of these emissions.

The rest of the paper is organized as follows. The following section outlines the main aspects of biological processes that determine pollution concentrations in water bodies (transportation, pathways, fate, degradation, etc.), and highlights the differences between these substances and already well-known contaminants. Section 3 then reviews the main environmental consequences and risks the emerging contaminants pose to both humans and ecosystems. Section 4 synthesizes the existing legislation to lay the groundwork for the economic analysis, while Section 5 presents and discusses the main challenges for water management and policy, along with the areas where further economic research is needed. The final section closes the paper with some conclusions.

\section{Occurrence and Biological Processes of Emerging Contaminants}

More than 140,000 new chemicals and pesticides have been synthesized since 1950 (Landrigan et al., 2018), 100 million chemical compounds have already been recorded in the Chemical Abstracts Service (CAS), and around 4,000 new substances are reported every day (Dulio et al., 2018). Additionally, world chemical production was valued at more than 3.6 billion $€$ (in 2019) and this is expected to almost double by 2030 according to the European Chemical Industry Council (CEFIC, 2021). The majority of these substances end up in the environment; notably, in 
water bodies. A recent study from the European Union (EU) detected 2.8 million sites within the EU potentially contaminated by hazardous chemicals (Payá Pérez and Eugenio, 2018). While most of these elements are not harmful, or at least not at low concentration rates, there is growing concern about the potential damage resulting from the combination of some of these substances and the increase in their concentration levels (Aristi et al., 2016; European Commission (EC), 2012).

Emerging pollutants are defined as synthetic or naturally occurring chemicals that enter the environment and can potentially cause harmful health effects in both ecosystems and humans (Geissen et al., 2015). They correspond to more than a thousand substances, categorized into about 20 classes, including pharmaceuticals, PCPs, pesticides, urban, or industrial chemical products (disinfection, cleaning, etc.). Even though some of these substances have been observed in the environment for quite some time, even decades, existing monitoring programs and legislation are still fragmented and messy and related biological processes, as well as their toxicity, are poorly understood. For this reason, institutions such as the United States Environmental Protection Agency (US EPA), consider it more appropriate to use the term CECs to denote these substances. According to Sauvé and Desrosiers (2014), CECs include different types of substances, not only pollutants that have very recently appeared in the environment because of the manufacturing of new products or the incorporation of new chemicals into the production processes, but also contaminants that were already known to exist in the environment and for which interest is currently increasing. An example of such new contaminants are flame-retardants, introduced not long ago to substitute polychlorinated biphenyls and polybrominated diphenyl ethers (PBDEs) when these were restricted or banned (Ward et al., 2008). Another example are neonicotinoids, which have been incorporated into farming activities as a new class of pesticides (Perry and Moschini, 2020). On the other hand, the emergence of new and better monitoring technologies (Anumol et al., 2013) with greater capacity to detect and identify contaminants has brought to light alarming concentrations of some substances in water bodies (e.g., various pharmaceuticals). Furthermore, concerns have also arisen due to increasing scientific evidence warning of the potential risks associated with some of these pollutants.

Most of the relevant substances, in terms of occurrence, identification, and potential impact, are mainly related to three categories: 
pharmaceutical, personal-care, and endocrine-disrupting compounds (Gogoi et al., 2018). However, recent studies have identified a large number of other potentially harmful compounds (Kroon et al., 2020; Stefanakis and Becker, 2015). Table 1 presents a general classification of CECs together with their main source of emissions. ${ }^{1}$

The increasing awareness of the accumulation of CECs in water bodies and their potential impact calls for a broad analysis of the dynamics of these substances. However, some properties of the CECs, such as their volatility, large adsorption, or persistence, which determine their transport and fate from the pollution source to water bodies (Farré et al., 2010; Geissen et al., 2010) complicate the understanding of their processes and dynamics. Thus, a major obstacle lies in identifying and assessing the occurrence of these contaminants. In general, most CECs originate from industrial and household wastewater (e.g., human medicines, PCPs, or industrial additives), because of limitations in abatement technologies. Yet, even though in general agricultural and farming activities are a less relevant source of emerging contaminants (Topp et al., 2008), they are an important emission source of pesticides, hormones, natural toxins, and veterinary medicines (Boxall, 2012). Figure 1 shows the main sources and pathways of CECs.

Besides pesticides and antibiotics used in the livestock sector, most CECs derive from urban and industrial uses (Figure 1) and enter the environment through wastewater treatment plants (WWTPs) responsible for household and industrial sewage treatment (Campo et al., 2016; Ccanccapa et al., 2016). WWTP removal efficiency is very heterogeneous (Deblonde et al., 2011; Luo et al., 2014) with substances like Ibuprofen, salicylic acid, or estradiol being efficiently removed (removal rate above $90 \%$ ), while others such as antibiotics like trimethoprim or diuretics (e.g., amidotrizoic acid, diatrizoate) presenting removal rates below $10 \%$ (Bellver-Domingo et al., 2017; Göbel et al., 2007; Torres-Padrón et al., 2020). In some cases, pollutants such as diclofenac, carbamazepine, erythromycin, and sulfamethoxazole have even been found in larger concentrations in effluent compared to influent water (Pal et al., 2010). The different transformation processes that take place in WWTPs have proven

${ }^{1} \mathrm{~A}$ complete classification of emerging pollutants is provided by the NORMAN Network, an international institution in charge of emerging environmental substances (www.norman-network.net). 
Table 1: Classification of CECs.

\begin{tabular}{|c|c|c|}
\hline Contaminant & Type of emissions & Source \\
\hline $\begin{array}{l}\text { Pharmaceutical } \\
\text { residues }\end{array}$ & $\begin{array}{l}\text { Biological active compounds (e.g., } \\
\text { antibiotics or anti-inflammatory } \\
\text { drugs) from human and } \\
\text { veterinary sources }\end{array}$ & $\begin{array}{l}\text { Urban (wastewater } \\
\text { discharge) and } \\
\text { agricultural }\end{array}$ \\
\hline $\begin{array}{l}\text { Personal-care } \\
\text { products } \\
\text { (PCPs) and } \\
\text { lifestyle } \\
\text { compounds }\end{array}$ & $\begin{array}{l}\text { Substances from personal-care } \\
\text { purposes (e.g., shampoos, } \\
\text { sunscreens, detergents, cosmetics, } \\
\text { etc.) } \\
\text { Pharmaceutics for human and } \\
\text { veterinary purposes } \\
\text { Sunscreens and ultraviolet filters } \\
\text { Steroids and hormones } \\
\text { Substances such as caffeine and } \\
\text { nicotine }\end{array}$ & $\begin{array}{l}\text { Urban (wastewater } \\
\text { discharge) }\end{array}$ \\
\hline $\begin{array}{l}\text { Endocrine } \\
\text { disruption } \\
\text { chemicals } \\
\text { (EDCs) }\end{array}$ & $\begin{array}{l}\text { Natural or synthetic chemicals } \\
\text { found in human and animal food }\end{array}$ & $\begin{array}{l}\text { Urban and agricultural } \\
\text { (Natural chemicals } \\
\text { found in human and } \\
\text { animal food) }\end{array}$ \\
\hline Heavy metals & Industrial compounds & Industrial \\
\hline Pesticides & $\begin{array}{l}\text { Agricultural substances to control } \\
\text { plagues and unwanted vegetation }\end{array}$ & Agricultural \\
\hline $\begin{array}{l}\text { Petroleum } \\
\text { hydrocar- } \\
\text { bons and } \\
\text { gasoline } \\
\text { additives }\end{array}$ & $\begin{array}{l}\text { Gasoline additives comprise more } \\
\text { than } 500 \text { substances to, for } \\
\text { example, improve petrol burning } \\
\text { efficiency (octane) }\end{array}$ & Industrial \\
\hline $\begin{array}{l}\text { Industrial } \\
\text { additives } \\
\text { and solvents }\end{array}$ & $\begin{array}{l}\text { Some examples are mercury, lead, } \\
\text { cadmium, thallium, or silver }\end{array}$ & $\begin{array}{l}\text { Industrial (wastewater } \\
\text { discharge) }\end{array}$ \\
\hline Microplastics & Plastic particles $(<5 \mathrm{~mm})$ & $\begin{array}{l}\text { Industrial and urban } \\
\text { (wastewater } \\
\text { discharge) }\end{array}$ \\
\hline Nanomaterials & $\begin{array}{l}\text { Substances used in sunscreen } \\
\text { products, transport, healthcare, } \\
\text { materials, energy, and } \\
\text { information technologies }\end{array}$ & Industrial \\
\hline
\end{tabular}

Source: Own elaboration based on Lapworth et al. (2012), Lei et al. (2015), and Petrie et al. (2015). 


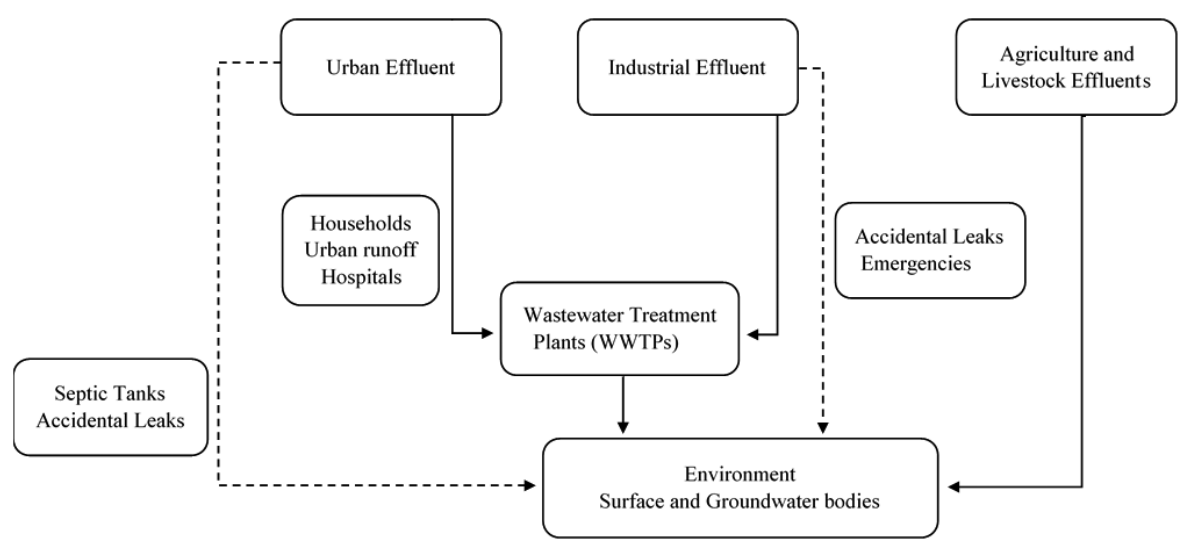

Figure 1: Diagram of the main sources of water pollution by CECs.

Source: Own elaboration based on Lapworth et al. (2012) and Stefanakis and Becker (2015).

to be insufficient to remove most of the CECs from wastewater. So, a high occurrence of CECs, both in terms of concentration and diversity of substances, has been identified in wastewater (Drewes et al., 2003).

To reduce the incidence of CECs, improvements in monitoring, detection, and removal technologies must be accompanied by an appropriate knowledge on the severity of the impact of the CECs which largely depends on their accumulation in the catchments. Biological buildup and degradation notably vary between the different pollutants. While nitrates have a degradation half-life time of 1-2 years, other substances like carbamazepine or primidone can persist in the environment for more than 8 years (Sinclair and Boxall, 2003). Furthermore, once released into the environment and degraded, some metabolites may be more toxic than the primary compounds (Bradley et al., 2008; Geissen et al., 2015). Hence, it is crucial to evaluate the impacts that these substances have on the environment and the possible risks for human and animal health.

Another relevant challenge related to CECs is the insufficient, or even nonexistent research, on some emerging contaminants. While some substances have been intensively analyzed (e.g., antibiotics, pharmaceutical, veterinary medicines), others remain poorly studied (Bunke et al., 2019). The selective interest in some substances is not only motivated from the residual number of technical and research studies but also because of a lack of regulation and/or political concern (Peña-Guzmán et al., 2019). 
On top of this, the technical analyses performed are concentrated in a few regions and in selected water bodies. For example, the analysis of CECs in groundwater resources lags far behind the research carried out on surface water bodies, and it is practically nonexistent in the case of certain water bodies such as lagoons and wetlands. Thus, more basic research needs to be conducted to identify key aspects in the biological processes and to shed light on the behavior of CECs. In this sense, promoting basic research into new substances encounters the problem of scarcity of time and resources, so it is necessary to establish criteria and protocols to efficiently allocate the limited resources available.

\section{Impacts of CECs on Ecosystems and Human Health}

The presence, incidence, and impact of new pollutants have on the aquatic environment is a growing concern (Bunke et al., 2019). In general, such impacts depend on the source, physicochemical characteristics, mobility, and behavior of the pollutants in the soil and/or in the aquatic environment (Stuart et al., 2012).

While there is strong evidence that exposure to some chemical contaminants from pesticides and herbicides has been responsible for developmental dysfunctions in children's brains (Grandjean and Landrigan, 2006, 2014), information on the toxicity and ability to harm human health (especially that of children) of other commonly used chemicals is rarely available. In fact, evaluations of the safety of new chemicals before they come to market is publicly available for only about half of the synthetic chemicals in current use, and information on their toxicity or capacity to harm infants and children is available for fewer than $20 \%$ of the most widely used synthetic chemicals (Braun et al., 2009; Landrigan et al., 2018). Apart from the harmful effects on humans, pesticides are also found to cause severe biodiversity losses. For instance, Beketov et al. (2013) found decreases in both species and family richness in stream invertebrates by up to $42 \%$ of recorded taxonomic pools due to the pesticides currently used in Europe and Australia.

Among the emerging pollutants, microplastics $(<5 \mathrm{~mm})$ and nanoplastics $(<10 \mathrm{~nm})$ have received increasing attention in recent years (Bläsing and Amelung, 2018; Wu et al., 2020). Generally, these plastic microfibers reach the water courses through leaching from soils and have 
their origin not only in nonpoint sources such as agriculture but also in point sources such as municipal and industrial wastewaters. The use of plastic mulching materials for horticultural production, for example, is very common in many countries because it saves water, eliminates, or reduces the use of herbicides and increases soil temperature. The studies that evaluate the effects of these particles emphasize that no standardized methods are available for plastic quantification in soil (Bläsing and Amelung, 2018), but it is highly likely that soils are significant, possibly dominant, environmental reservoirs of microplastics and nanoplastics (Hurley and Nizzetto, 2018). In particular, da Costa et al. (2016) and Alimi et al. (2018) emphasize that nanoplastics have a greater affinity for adsorption of contaminants and can act as carriers of pollutants, which exhibit a more dangerous effect on humans and ecosystems (e.g., metals and persistent organic pollutants), to facilitate their transport. Despite the lack of conclusive data, it has been reported that microplastics and nanoplastics can be accumulated in food chains and are biotoxic to organisms (de Souza Machado et al., 2018). For instance, plastic microfibers like asbestos can be carcinogenic (Re, 2019). From a management perspective, the analyses should focus on the dynamics of these plastics in order to detect vulnerable soils in which the use of plastics should be decreased or banned, as many of the so-called "biodegradable" materials do not degrade completely in soils (Miles et al., 2017).

With regard to pharmaceutical products such as anti-inflammatory and antibiotic drugs, they come from the WWTPs (Fonseca et al., 2020; Johnson et al., 2017; Rodriguez-Mozaz et al., 2020) and intensive livestock activities (Gonzalez Ronquillo and Angeles Hernandez, 2017; Lekagul et al., 2019; Mund et al., 2017). Despite having been found at relatively low concentrations in the environment (Ebele et al., 2017), there is evidence that they have toxic interactions with aquatic organisms and also with the organic (Ebele et al., 2017) matter of soils (see Sathishkumar et al. (2020) for a complete review of studies). The presence of antibiotics from veterinary and medical uses, even in low concentrations, is known to stimulate the emergence of resistant bacteria and may be toxic to aquatic organisms, plants, and even mammals (Álvarez-Esmorís et al., 2020; Frade et al., 2014). An important concern related to antibiotics is the potential creation of antibiotic-resistant bacteria that can hinder effective treatment options against animals' 
infectious diseases (Ebele et al., 2020). Antibiotics impair natural biofilms as they can kill native bacteria and cause antibiotic-resistant bacterial families to remain. The accumulation of these substances in plants (including edible fruits and vegetables) could also have toxic effects on mammals and affect human health when they enter into the food chain (Bartrons and Peñuelas, 2017; González García et al., 2018). In particular, it has been found that co-infection of patients in Intensive Care Units is an important factor resulting in lower survival rates due to antimicrobial resistance (Liu et al., 2018; Zhou et al., 2020). In addition, the effects of the unintentional consumption of antibiotics through the food chain is frequently aggravated by an abuse in antimicrobial therapy. For instance, Rawson et al. (2020) found that $72 \%$ of COVID-19 patients received antibiotics during hospital admission, while less than $10 \%$ experienced bacterial/fungal coinfections. Thus, some studies warn that a marked increase in antibiotic-resistant bacteria should be expected (Miranda et al., 2020) and this will cause millions of human deaths annually by 2050 (Kost, 2021).

Similarly, it has been reported that PCPs such as UV filters/sunscreens affect phytoplankton and tend to accumulate in the food chain, disturbing the equilibrium of aquatic ecosystems (Castaño-Sánchez et al., 2020). They can also interfere with endogenous hormone systems and hinder the reproductive capacity of some aquatic species (Gavrilescu et al., 2015), thus posing a serious threat to the exploitation of species used for human consumption.

Some chemicals in common PCPs, such as soaps, creams, perfumes, and shampoos act as endocrine disruptors in aquatic organisms. These include phthalates, bisphenol A, perchlorate, certain pesticides, brominated flame retardants, certain metals, and dioxins that can interfere with endocrine (or hormonal) systems. It is proven that exposure to endocrine disruptors during sensitive periods in early human embryonic development can lead to permanent impairments in organ function and to increased risk of disease (Landrigan et al., 2018). However, the specific contribution of these substances to the overall disease burden has not yet been quantified. Endocrine disruptors can also decrease reproductive levels in aquatic fauna such as fish species. Although they may have low acute toxicity, a decrease in reproductive rates even at very low levels of exposure leads to a reduction in fish stocks and increases the risk of overfishing and species extinction. Moreover, the effects of 
exposure during early life may not be observed until adulthood, so it is very important to conduct long-term eco-toxicity studies (Gavrilescu et al., 2015).

In the specific case of aquifers, in parallel with the over-extraction of water, subterranean ecosystems are threatened by anthropogenic pollutants, including metals, pesticides, fertilizers, emerging contaminants, and volatile organic compounds (Castaño-Sánchez et al., 2020). Groundwater organisms are known to play a critical role in functions that provide ecosystem services, including the maintenance of water quality and supporting groundwater-dependent ecosystems such as springs and rivers (Griebler et al., 2014). These ecosystems can be seriously affected by all these isolated substances, but also by a mixture of all of them even in small concentrations. So, it is necessary to establish the toxicological effects of these substances and to implement protection thresholds.

In the case of other components present in medicines, such as antiinflammatory drugs, the long-term consequences for aquatic ecosystems and human health are still unknown. Furthermore, the fact that terrestrial subterranean ecosystems are intimately linked with the groundwater cycle is also neglected, and thus scientific information concerning the effect of pollution in these ecosystems is needed for their effective protection.

\section{Existing Legislation}

Currently, policy-makers agree that there is an urgent need to address CECs in a systematic and coherent manner (Dulio et al., 2018). To this end, various programs, and legislation have been developed.

In Europe, the Water Framework Directive (WFD) (Directive $2000 / 60 /$ EC) laid down the basis for determining which pollutants may pose a significant risk to or via the aquatic environment, and thus should be subject to monitoring. The first list, created under Decision No $2455 / 2001 /$ EC, which would become annex X to the WFD, included 33 CECs. Of these substances, 11 were classified as priority hazardous substances, that is, substances for which Member States should implement the necessary measures in order to interrupt or phase out emissions, discharges, and losses within a maximum period of 20 years. 
The other 14 substances were subject to a subsequent review. Later, the Environmental Quality Standards Directive (Directive 2008/105/EC), also known as the Priority Substances Directive, modified the list and specified maximum allowable concentrations of selected substances in surface waters. This second list was replaced again in 2013 (Annex I to Directive 2013/39/EU), with the incorporation of 12 additional substances of major concern, adding up to a total of 45 pollutants, out of which 21 were classified as priority hazardous substances. Directive 2013/39/EU established stricter environmental quality standards (EQS) for some of these substances, as well as additional provisions on persistent pollutants and pharmaceuticals. Moreover, a Watch List of substances has been created to guide future prioritization. These directives have been complemented with the Sustainable Use Directive for pesticides (Directive 2009/128/EC) and the Industrial Emissions Directive (Directive 2010/75/EU).

The former pieces of legislation required Member States to set up an inventory of emissions, discharges, and losses of these substances, and fostered the creation of the Registration, Evaluation, Authorisation and Restriction of Chemicals (REACH) register for chemical substances in 2007 (Regulation (EC) No 1907/2006). In the REACH, the burden of proof falls upon companies who need to demonstrate how the chemical substances they manufacture and market in the EU can be safely used. Further, they must also identify associated hazards and communicate risk management measures to the users. That same year, the European Pollutant Release and Transfer Register (Regulation (EC) No 166/2006) was created. The register required more than 30,000 industrial facilities to provide information about their emissions from a list of 91 pollutants, covering various heavy metals, pesticides, greenhouse gases, and dioxins.

Although progress has been made in the regulation of these pollutants (e.g., all river management plans for the timeframe 2015-2021 already need to take into account the EQS set by the European legislation), there is still much to be done in the case of groundwater, where regulation is scarce and very heterogeneous. In this respect, the Groundwater Directive (GWD, Directive 2006/118/EC) only established unified EQS for nitrates and pesticides. Moreover, even though this Directive called for the establishment of national/local quality standards, the specified thresholds differ widely among the Member States, both in terms of the number of compounds subject to regulation and in the 
specific threshold values, which in some cases differ by two or even three orders of magnitude (Scheidleder, 2012).

Recently, the EU has promoted the European Green Deal, which aims at making Europe the first climate-neutral continent by 2050. As part of the Green Deal strategy, the European Commission published a chemicals strategy for sustainability in 2020 with the aim to simplify and consolidate the implementation of EU rules concerning chemicals. It has some relevant features, such as a long-term vision for EU chemical policy, a zero-tolerance approach to noncompliance, a gradual move from assessing and regulating single chemicals to handling them by groups, and a promotion of harmonized human and environmental health-based limit values, including the establishment of coordination mechanisms.

In the context of the Green Deal program, the European Commission (EC) also unveiled its Farm to Fork and Biodiversity Strategies, which will impose restrictions on EU agriculture through targeted reductions in the use of land (10\%), fertilizers (50\%), antimicrobials in livestock production $^{2}$ (including aquaculture) (50\%), and pesticides (50\%) by 2030. In parallel, the Green Deal aims to promote organic production since it generates relevant benefits such as higher biodiversity levels and lower use of antibiotics in livestock care. It also pursues the incorporation of precision farming techniques to improve efficiency in the use of agricultural inputs and to compensate for expected production losses. Furthermore, the Green Deal intends to modify current consumption patterns toward sustainable produced foods. However, proposed agreements are not complemented by economic studies evaluating the expected environmental costs and benefits and/or the final level of pollutant emissions.

In this regard, it is essential to conduct robust impact assessments of policy options to determine the potential trade-offs between different climate and environmental objectives. Specifically, the land issue requires special attention, since the de-intensification of practices and the increases in organic systems implicitly included in the Green Deal could require more agricultural land, with possible adverse ecological consequences. On the other hand, lower yields induced by less intensive

\footnotetext{
${ }^{2}$ To decrease veterinary medical product use and harmonize EU countries' policies, the EU recently adopted Regulation (EU) 2019/6 on Veterinary Medicinal Products and Regulation (EU) 2019/4 on Medicated Feed, which will come into effect as of 2022 .
} 
production will increase the unit cost of production and thus increase food prices, consequently altering the competitiveness of the agricultural sector. In a global world, both effects may have an impact on the flow of imports from third countries that may result in pollution shifts instead of an overall reduction.

In the United States, the US EPA is also working on the analysis of pollutants of emerging concern to advance in the necessary knowledge for their regulation. However, the Guidelines for Deriving Numerical National Water Quality Criteria for the Protection of Aquatic Life and Their Uses date from 1985, and may, therefore, not be adequate to determine the potential risks of new pollutants. Thus, in order to address pollution of CECs and lay down a water quality protection strategy, the Workgroup OW/ORD Emerging Contaminants (2008) developed a white paper entitled: aquatic life criteria for contaminants of emerging concern, Part I: general challenges and recommendations, to modify the old guidelines. Following the Safe Drinking Water Act (SDWA), the US EPA has established quality standards in drinking waters for more than 90 pollutants to ensure adequate protection of drinking water and its sources. However, the SDWA does not provide regulation for private wells with less than 25 users, despite being estimated that more than 13 million households (43 million people) rely on private wells for their drinking water. This is especially relevant since it implies that about $15 \%$ of the US population remains outside the regulatory framework and, therefore, subject to CECs repercussions and risks (US Census American Housing Survey, 2017). ${ }^{3}$

To conclude, most of the current policies are based on defining maximum contaminant levels, either limiting or directly banning the use of products, or in the form of maximum concentrations in water that need to be met. Furthermore, only few of these regulations propose economic incentives to be used. ${ }^{4}$ Moreover, in most countries, the externalities resulting from the use of CECs are dealt with in different ministries (e.g., health, agriculture, environment, economic development), and thus the full magnitude of the impacts of water pollution is often not recognized (Landrigan et al., 2018). As a consequence, the regulations

\footnotetext{
${ }^{3}$ Available at https://www.census.gov/programs-surveys/ahs/data/interactive/ ahstablecreator.html

${ }^{4}$ For example, in EU farmers can obtain partial market price subsidies by using a biodegradable mulch in their horticultural production (Marí et al., 2019).
} 
of the various agencies may not be aligned, and the potential policy coordination failures could lead to an exacerbation of environmental damages (Bennear and Stavins, 2007).

\section{Challenges for Water Management and Policy}

To date, the most studied water pollutants have been nitrates and phosphates, which have also been by far the most regulated. Thus, water quality has been mostly associated to the presence of these nutrients in water (Martín-López et al., 2014). Since WWTPs have become very efficient in removing nitrogen and phosphorus from human and industrial origins, the main source of water pollution from these substances is agriculture. Consequently, water pollution control measures have traditionally focused on agricultural pollution loads, and an extensive amount of literature has been developed to propose and assess economic instruments to decrease agricultural pollution.

Nonpoint pollution from agriculture (farmlands runoff and percolation) and intensive livestock is characterized by the lack of information on the agent and location responsible for the emission. Furthermore, there are several uncertainties in the transport and fate processes of these emissions. However, the existence of worldwide regulations to control and reduce the pollution caused by nitrates and pesticides from water bodies has promoted the proliferation of instruments to deal with these externalities. From an economic point of view, two main mechanisms have been suggested to limit agricultural nonpoint pollution: the implementation of pure economic instruments such as water pricing structures, taxes/subsidies to both output and input, or the implementation of effluent permit trading (Fisher-Vanden and Olmstead, 2013; Pearce and Koundouri, 2003b; Shortle, 2017; Shortle and Horan, 2013). In several cases, economic instruments are accompanied by the implementation of water quality standards and water use restrictions (command-and-control instruments). The main advantage in the regulation and implementation of policy instruments in the case of nutrients is the existence of an adequate regulatory scheme and wellestablished upper limits on the concentration levels of these pollutants. The existence of an extensive body of literature on the impacts of these 
substances allowed for the implementation of efficient policies (Andersen et al., 2011).

Compared to nutrients, CECs have some distinctive characteristics that pose new challenges for water economics and policy. To elucidate the greater or lesser need for action and the type of policies to be implemented, it is essential to build up economic knowledge on the use of CECs, how they enter the environment, their resulting impacts, and the feasibility and costs of their elimination. The areas revolving around these main points, on which it is necessary to focus research efforts to achieve an adequate CECs management policy, are presented below.

\subsection{Introduction of CECs into the Environment}

First of all, it is necessary to increase the amount of data and knowledge on the key aspects that affect the occurrence of emerging contaminants in different countries and regions. Issues such as the structure of the economy, or the level of economic development will undeniably condition the appearance and expansion of CECs.

Furthermore, the current problems of CECs will be aggravated because of the expected climate change impacts that will involve higher incidences of extreme water events such as an increase in the frequency and magnitude of drought periods. Reductions in water flows will lead to an increase in the pollutant concentration and a reduction in dilution capacity that will threaten the functioning of water bodies (Bunke et al., 2019). This is an important problem for arid and semiarid regions where water scarcity is going to increase. On the other hand, the increase in the incidence of flood events will involve the mobilization of several pollutants that remain in soils but will be transported to water bodies (Schiedek et al., 2007; Whitehead et al., 2009). Furthermore, climate change impacts on food availability and crops yields, together with an increasing food demand, will trigger agricultural production. In this regard, the use of pesticides is expected to increase causing an increase in the risk of insecticide exposure (Kattwinkel et al., 2011), which will increase the proportion of streams close to farmland that do not comply with the requirements of good ecological status, for example as in those defined by the WFD.

In a context of water scarcity, water recycling, by reusing treated wastewater from municipalities and industries, has become a potential 
solution. Currently, recycled water is in general used for nonpotable uses such as irrigated agriculture, residential, and urban uses (e.g., gardening, flushing, car washing, irrigation of public parks, streets cleaning, etc.) and industrial needs (e.g., cooling applications in power plants). Yet, this source of freshwater can also be used for the replenishment of depleted water bodies such as aquifers, reservoirs, and even some ecosystems, such as wetlands. Therefore, water policies are already including water reuse as a solution to address water scarcity (Pistocchi et al., 2017). However, the important amount of emerging contaminants that this practice can introduce into the environment is still totally ignored (Snow et al., 2019). If the concentrations of emerging compounds reach critical levels, the reuse of these resources can be compromised. In order to reuse water resources, tertiary treatments are required to remove toxic and potentially harmful compounds (Voulvoulis, 2018). However, even tertiary treatments are not completely efficient in removing all possible contaminants and, furthermore, the level of treatment will largely depend on the overall quality of the water resource. The lack of information on the costs and benefits of using this resource and the difficulty in identifying the concentration and occurrence of several CECs hinders the correct processing of recycled water.

Further, many of the CECs come from consumption activities, so economic analysis can be essential to identify the most effective economic instruments according to the characteristics of the demand (Belay and Jensen, 2020). Economic development is closely linked to changes in consumption and production patterns, which eventually trigger the incorporation of new CECs into the supply chain. Moreover, population growth will exacerbate the generation of pollutants if not managed properly, for instance, those found in PCPs and medicines. ${ }^{5}$ Other factors, such as the structure of production or the size of the informal economy, might also impact CECs emissions. In particular, activities from the hidden economy are generally not easy to monitor and regulate. As a result, economies with a larger informal sector tend to have greater

\footnotetext{
${ }^{5}$ Robertson et al. (2021) reported notable differences in antibiotic use in the European Region; total consumption in 2018 ranged from 8.9 defined daily doses per 1,000 inhabitants per day in Azerbaijan to 15.5 in Denmark or to 34.1 in Greece. Moreover, temporal trends diverge between the countries analyzed, illustrating the variety of surveillance efforts and actions being taken to address antimicrobial resistance.
} 
emissions of water pollutants (metals and solvents from industrial work, pesticides, and fertilizers). For example, in informal mining activities, the chemicals used to wash the minerals end in wastewater and are directly dumped into rivers and other water bodies (Bali Swain et al., 2020). Another illustrative example is illicit cannabis cultivation that leads to significant impacts on the environment. In the case of outdoor cultivation, it causes deforestation and extensive irrigation, with an overuse of fertilizers, pesticides, and rodenticides (Thompson et al., 2014; Warren, 2015).

In addition, many of the compounds posing significant risks result from products that are no longer manufactured. For instance, even though PBDE was banned in 2004, it still forms part of several final goods such as furniture, mattresses, and electronic devices, which are still in use (Ward et al., 2008). Besides, technological appliances and furniture contain multiplicity of other toxicants apart from PBDE (e.g., $\mathrm{Pb}, \mathrm{Cd}, \mathrm{Hg}, \mathrm{Cr}$, plastics, and other persistent organic pollutants). Once these products become obsolete or reach the end of their lifetime, most of them end up in landfills because of their low cost of disposal. Rainfall then provokes the leaching of these contaminants into groundwater (Seeberger et al., 2016). Although the world economy produced a total of 53.6 million tons of electronic waste in 2019 , only a mere $17.4 \%$ was properly collected and recycled. Moreover, e-waste is forecasted to grow to 74.7 million tons by 2030 (Forti et al., 2020). So, projections indicate that a great amount of CECs will continue to enter water bodies in the future through the disposal of these products and subsequent leachate. Current prohibitions do not prevent them from entering the environment, and regulations such as quotas or limitations on their use may not be sufficient. There is, therefore, the need to advance economic analyses of waste removal.

\subsection{Economic Analysis of CECs Impacts}

As with the buildup of CECs, their impacts are still not well cataloged or analyzed. This issue hinders the correct implementation of policy mechanisms to reduce the concentration of several of these substances in water bodies. The Safe Drinking Water Act requires the US EPA to perform cost-benefit analyses (CBA) for establishing its water regulations and maximum concentration thresholds. The WFD also demands 
cost-benefit analyses to design appropriate environmental policies. However, this is certainly no easy task. While the costs of removing CECs are not excessively complicated to calculate, their benefits are often not incorporated or correctly assessed due to the lack of a standard methodology for their monetary valuation.

Thus, proper economic assessments of the effects of these new substances such as in Lai (2017) are necessary to evaluate the suitability of different economic measures such as direct regulations or economic incentives (Hoel and Karp, 2002). Moreover, economic instruments will need to be carefully adapted to the characteristics of these new pollutants. For instance, while policies based on voluntary compliance, decentralized monitoring, and cooperation between agents could work to control pollution in certain agricultural settings, they may not be feasible for pollutants derived from human consumption of plastics, medicines, and PCPs. Scientific evidence regarding the irreversibility of the negative effects caused to aquatic organisms should be translated into more stringent marketing regulations for all these products, including toxicity analyses and especially applying the precautionary principle.

Moreover, one of the greatest challenges to CECs management is to approach it from a global perspective, rather than the common, fragmented regulatory framework. Most of the literature focuses on avoiding the impacts of a single pollutant (e.g., nitrogen or phosphorous), while tens of thousands of new chemicals that are potentially harmful to the environment are found in personal care and other quotidian products (Schwarzenbach et al., 2006) and are jointly released into the environment. Many of these substances have synergistic and additive effects, which entails that, even though the problems arising from a particular pollutant may not be significant, the combined effects of some of them can be of great magnitude (Dulio et al., 2018). For instance, pollution from CECs has been shown to interact with nutrient emissions. The antibacterial properties of antibiotics inhibit microbial activity in aquatic environments, which leads to a reduction in nitrogen removal rates and a subsequent increase in the formation of $\mathrm{N}_{2} \mathrm{O}$, an intermediate of the nitrate reduction process and greenhouse gas that contributes to global warming ( $\mathrm{Xu}$ et al., 2020). Thus, more research assessing the environmental damage and risks from pollutant mixtures is of utmost importance. 


\subsection{Economic Analysis of CECs Removal}

One of the main difficulties of adapting and employing existing policies resides in the biophysical nature of CECs, which is in general different from that of nutrients. As discussed in Section 2, most emerging compounds end up in water bodies as a result of the low removal efficiency of conventional WWTPs with respect to several of the emerging contaminants (Margot et al., 2013; Mohapatra and Kirpalani, 2019; Stefanakis and Becker, 2015). Conventional WWTP technologies are not designed to detect and/or remove several biological and organic substances coming from products used in everyday life, which are, in a large portion, part of the household and industry sewage. Technical research has been focused on improving the capacity of WWTPs to effectively remove the occurrence of emerging contaminants, and advances in wastewater technologies have been achieved (Margot et al., 2013; Mohapatra and Kirpalani, 2019; Petrović et al., 2003). However, to date, all existing technologies involve advantages but also several challenges, limitations and gaps that should be carefully weighed. An example is the case of biological processes, which happen to be widely used because of their low operating costs and high availability, but exhibit low-efficiency rates when it comes to removing several micropollutants. Another example is the case of tertiary treatment processes, which are superior compared to primary and secondary treatments in terms of the removal of CECs from wastewater (e.g., granular activated carbon adsorption), but involve higher operational costs and a greater impact in terms of energy use. In this sense, some studies signal the existence of a "trade-off" in the use of these technologies, since these are capable of removing CECs, but also contribute to generating significant $\mathrm{CO}_{2}$ emissions because of their intense energy use (Stuart et al., 2011). A high level of cleanliness may also be inadequate since the large quantity of chemicals used for water treatment will, ultimately, lead to an increase in the amount of solid waste generated (Gross and Park, 2018). Additionally, some processes (e.g., oxidation processes) which are very efficient in the removal of several pollutants have the disadvantage of creating intermediates substances that, in some cases, are more toxic than the initial compounds (Vasilachi et al., 2021).

Based on the above, it is evident that in-depth studies are still necessary to identify the main challenges related to the development of 
more efficient removal technologies for WWTPs. Technological studies need to assess the investments required to improve current WWTPs, their efficiency in removing the most toxic and dangerous contaminants, and the possible side effects of their implementation. However, the great need for technical systems that can mitigate the occurrence of CECs is accompanied by the need for socio-economic studies evaluating the cost-effectiveness of the different treatment technologies in removing these substances from the water bodies. There are very few studies that measure the environmental benefits of CEC removal. MolinosSenante et al. (2013) estimate the shadow prices for five substances (galaxolide, tonalide, sulfamethoxazole, diclofenac, and ethinylestradiol), which correspond to the environmental benefit that would be generated if these compounds were removed from wastewaters. Bellver-Domingo et al. (2018) provide monetary values of not discharging salicylic acid, methylparaben, and THCOOH into wetlands. Bellver-Domingo et al. (2017) also estimated shadow prices for the elimination of five pollutants in different ecosystems (wetlands, rivers, and the sea).

Yet, Gurian et al. (2004) point out the necessity of conducting CBA of attaining threshold limits for multiple CECs. Since these substances interact with each other, a treatment process aimed at removing a particular pollutant may also serve to eliminate other contaminants. Consequently, the employment of fragmented and disconnected costbenefit studies, which take only one pollutant into account, will produce inaccurate estimates of the cost-efficiency of CEC removal and lead to erroneous economic policy decisions. Moreover, the economic studies need to deal with the existence of "trade-offs" and any negative externalities associated with the improvement of WWTPs. There is a need to balance environmental tradeoffs and evaluate the optimal mix of efficient yet energy-consuming source abatement versus environmental damage of remaining CECs.

Besides improving treatment technologies, upstream ecosystems and land-use types may also influence water quality and the subsequent costs of water treatment. Several studies have examined the efficiency of buffer strips or constructed wetlands for the removal of nitrates (Ghermandi et al., 2010). Significant results have also been found concerning the role upstream forests play as filters of Escherichia coli (a pathogen responsible for disease outbreaks) in downstream waters (Westling et al., 2020). Thus, existing information should be complemented with the 
assessment of the economic efficiency of the ecosystems to naturally mitigate the introduction of CECs into drinking water.

\subsection{Economics and Policy Design}

As the emergence of new substances has multiplied research needs, the provision of information has become an economic problem. A firstbest policy for the management of CECs would require several steps: (i) an assessment of current and future exposure to CECs with and without regulation; (ii) a behavioral model capturing economic agents' reactions to the true costs of compliance; (iii) dose-response functions to estimate the link between exposure levels and environmental and health effects; and (iv) a method for assigning monetary values to changes in exposures so that benefits can be compared with compliance costs (Pearce and Koundouri, 2003a). Unfortunately, this procedure requires a large amount of research, so time constraints and limited research funding make a first-best approach likely to be unfeasible. Regulators, therefore, are often compelled to use a second-best framework for policy design (Lipsey and Lancaster, 1956). For instance, most regulatory instruments use the action instead of the outcome or result as their base of compliance. With this in mind, economics could provide information to establish the link between the compliance base (e.g., polluting action vs. outcome) and the incentive/regulatory mechanism applied to this compliance base (economic incentives vs. direct control). Taking the use of antibiotics in livestock production as an example, economic studies may help to determine whether it is more cost-effective to act against the final emissions or against the initial action (on-farm use). In order to effectively control the action, research should focus on establishing the relationship between the prevalence of resistant bacteria in an area with the intensity and timing of this action. This would provide adequate information to establish effective regulations.

In policy design, a key factor is the way in which agents respond to implemented regulations. For instance, antibiotics in veterinary medicine can be seen as a risk-decreasing input, leading to an overuse by risk-averse farmers to prevent animal diseases. When farmers estimate potential risks, their evaluations mainly rely on their ability to judge animal health status and their knowledge about appropriate practices (Raboisson et al., 2020). However, a policy that increases the availability 
of knowledge about "best practices", will not necessarily modify farmers' behavior on antibiotic application. That is, farmers cannot appropriate from the future benefits of reducing animals' antimicrobial resistance, since this is a public good. Thus, they will have low incentives to change their actions unless they are compensated for their foregone profits, or there is an increase in the willingness to pay to consume meat from animals that have received low or no antibiotic treatment (Denver et al., 2021). Therefore, there is a need to improve our understanding of the underlying drivers and barriers (e.g., market prices, costs) to adopting "best practices" with regard to animal health (Fischer et al., 2019; Jones et al., 2016).

Behavioral changes occur because the implementation of CEC control measures modify the benefits that economic agents can obtain from the resources and services of ecosystems (Bennear and Stavins, 2007). As an example, the United Kingdom and Sweden reduced the use of trimethoprim and sulfonamide antibiotics to fight against antimicrobial resistance but the latter was not decreased because of antibiotic replacement processes (Roope et al., 2019). Thus, a reduction or elimination of a particular compound (e.g., antibiotic, pesticide or herbicide) could lead to its substitution by a different substance with greater environmental impacts on the same environment (aquatic ecosystem) or on other resources (air, soil, etc.). As indicated by Pardo and Martínez (2019), a ban on the use of the herbicide glyphosate in agriculture would lead to an increase in the use of other chemical herbicides that are less effective in controlling weeds and involve greater environmental impacts. In a similar way, Perry and Moschini (2020) found that the introduction of neonicotinoids has increased the toxicity risk to honeybees but has significantly lowered the risk to mammals, birds, and fish. They also found a neonicotinoid ban in US maize would likely induce farmers to change their insecticide usage patterns and replace them with more hazardous compounds such as organophosphates and other insecticides with unintended undesirable consequences. Therefore, taxing or banning a single chemical may not make sense. In this respect, Pearce and Koundouri (2003b) state the importance of assessing cross-elasticities besides own-price elasticities of pesticides, and suggest toxicity weighted taxes would capture geographic and product variation in damage better than a single tax. Likewise, eliminating the use of petrochemical plastics or agrochemicals may lead to their replacement by other factors of 
production (i.e., other materials or mechanical techniques), increasing the use of other resources such as land, water or fossil fuels, which affect air pollutant emissions (Brizga et al., 2020; Pardo and Martínez, 2019). Thus, it is crucial to take into account the environmental and biological dimensions in the economic analyses so that the feasibility of regulations and the substitution effects between different products are properly assessed in order to design efficient policies.

\section{Concluding Remarks}

Despite the large impacts CECs have on both ecosystems and human health (Schwarzenbach et al., 2006), they are still not thoroughly analyzed and related water regulations are fragmented and inconsistent. Some examples analyzed in the literature show that, in fact, some well-intentioned water quality regulation objectives may nevertheless be economically unfeasible with current technology, generate undesirable impacts on other resources, or even contribute to climate change. The development of policies to reduce the risks of CECs and ensure their control needs to be grounded in sound technical and economic research. Although the biological, chemical, and other related literatures are still partial and incomplete, there have been a great deal of effort made in the formation of technical knowledge on the transport and fate processes of these contaminants, as well as, on their toxicity and impacts. However, these studies mostly elude proper economic analyses, thus preventing an adequate evaluation of the implications of the results. Without this information, the management of water bodies taking into account the threats these substances pose is still far from being accomplished.

This paper has reviewed existing technological and economic studies on CECs to highlight key areas where economic science needs to focus its attention to guide the design of water policies. In summary, the previous studies suggest that the changes required for the management of CECs revolve around various fundamental aspects:

(i) The need for scientific evidence to generate protocols for measuring the presence and eco-toxicity of these contaminants and the way they are introduced into the environment. Because economic activities are fundamental drivers of the emergence of CECs, it is essential that the effects the consumption and production patterns of the economy 
can have on CECs are studied from an integrated perspective. That is, to take into account the synergies and substitution effects of these pollutants while also considering the overall life cycle assessment (i.e., including the generation of hazard compounds from waste disposal). Economic studies are crucial to identify and quantify substitution effects, synergy effects and economic feasibility of achieving emission reduction targets.

(ii) The importance WWTPs have as the main source of entry of CECs into the environment and, therefore, the need for greater monitoring and control, coupled with the development of new technologies. Diverse techniques are suggested in the literature to remove the occurrence of CECs from wastewater, and all of them differ in the inputs needed, costs, and removal rates. Thus, it is necessary to balance lower health and ecosystem impacts resulting from higher removal efficiencies with the need for additional materials and/or energy, which could unavoidably entail other environmental impacts.

(iii) Comprehensive multidisciplinary policy framework that accounts for CEC impacts through the inclusion of ecosystem services. Economic studies are also essential in this last area, so that progress can be made in the design of methods and instruments allowing for the inclusion of the economic value of the ecosystem services. Reducing all these harmful effects is a challenge in many aspects of the current water resource management, since it implies not only changes in production processes of many sectors (especially in agriculture and livestock), but also in consumption habits, and even in health and hygienic standards. Effective solutions require changes in the economic incentives underlying individual and collective economic behaviors (Shortle, 2017). In addition, the precautionary principle should be strongly included in the regulation of chemicals prior to their launch on the market by incorporating economic evaluation methods such as the quantification of avoided costs.

The amount of information required to develop a "first best" policy for an efficient management of CECs makes it a Herculean task. Therefore, in a second-best (or $n$th best) world, economic analyses can guide the research efforts in order to design more efficient and effective policies, for example, by clarifying the link between the basis of compliance and the regulatory mechanisms applied to it. In this respect, it is important 
the analyses include the unintended changes that regulatory policies may induce in agents' behavior.

\section{Funding}

The work presented here is part of the ARCO project, funded by the Spanish Government, Ministerio de Economía y Competitividad grant ECO2016-75927-R (AEI/FEDER/UE), the INIA project RTA201700082-00-00 funded by the Spanish Ministry of Agriculture and Fisheries, Food and Environment and the Spanish Government project PID2020115495RA-I0.

\section{Conflicts of Interest}

The authors declare no conflict of interest.

\section{References}

Alimi, O. S., J. F. Budarz, L. M. Hernandez, and N. Tufenkji. 2018. "Microplastics and Nanoplastics in Aquatic Environments: Aggregation, Deposition, and Enhanced Contaminant Transport". Environmental Science $\& 3$ Technology. 52(4): 1704-24. https://doi.org/10. 1021/acs.est.7b05559.

Álvarez-Esmorís, C., M. Conde-Cid, G. Ferreira-Coelho, M. J. Fernández-Sanjurjo, A. Núñez-Delgado, E. Álvarez-Rodríguez, and M. Arias-Estévez. 2020. "Adsorption/Desorption of Sulfamethoxypyridazine and Enrofloxacin in Agricultural Soils". Science of the Total Environment. 706: 136015. https://doi.org/10. 1016/j.scitotenv.2019.136015.

Andersen, M. S., M. S. Hansen, J. Carstensen, B. Kronvang, H. E. Andersen, and H. Thodsen. 2011. "Monetary Valuation with Impact Pathway Analysis: Benefits of Reducing Nitrate Leaching in European Catchments". International Review of Environmental and Resource Economics. 5(3): 199-244. https://doi.org/10.1561/101.00000042. 
Anumol, T., S. Merel, B. O. Clarke, and S. A. Snyder. 2013. "Ultra High Performance Liquid Chromatography Tandem Mass Spectrometry for Rapid Analysis of Trace Organic Contaminants in Water". Chemistry Central Journal. 7(1): 1-14. https://doi.org/10.1186/1752153X-7-104.

Aristi, I., M. Casellas, A. Elosegi, S. Insa, M. Petrovic, S. Sabater, and V. Acuña. 2016. "Nutrients versus Emerging Contaminants - Or A Dynamic Match between Subsidy and Stress Effects on Stream Biofilms". Environmental Pollution. 212: 208-15. https://doi.org/10. 1016/j.envpol.2016.01.067.

Bali Swain, R., U. S. Kambhampati, and A. Karimu. 2020. "Regulation, Governance and the Role of the Informal Sector in Influencing Environmental Quality?" Ecological Economics. 173(September 2019): 106649. https://doi.org/10.1016/j.ecolecon.2020.106649.

Bartrons, M. and J. Peñuelas. 2017. "Pharmaceuticals and PersonalCare Products in Plants". Trends in Plant Science. 22(3): 194-203. https://doi.org/10.1016/j.tplants.2016.12.010.

Beketov, M. A., B. J. Kefford, R. B. Schäfer, and M. Liess. 2013. "Pesticides Reduce Regional Biodiversity of Stream Invertebrates". Proceedings of the National Academy of Sciences. 110(27): 11039-43. https://doi.org/10.1073/pnas.1305618110.

Belay, D. G. and J. D. Jensen. 2020. "The Scarlet Letters': Information Disclosure and Self-regulation: Evidence from Antibiotic use in Denmark". Journal of Environmental Economics and Management. 104: 102385. https://doi.org/10.1016/j.jeem.2020.102385.

Bellver-Domingo, A., R. Fuentes, and F. Hernández-Sancho. 2017. "Shadow Prices of Emerging Pollutants in Wastewater Treatment Plants: Quantification of Environmental Externalities". Journal of Environmental Management. 203: 439-47. https://doi.org/10.1016/ j.jenvman.2017.08.025.

Bellver-Domingo, Á., R. Fuentes, F. Hernández-Sancho, E. Carmona, Y. Picó, and V. Hernández-Chover. 2018. "Monetary Valuation of Salicylic Acid, Methylparaben and THCOOH in a Mediterranean Coastal Wetland through the Shadow Prices Methodology". Science of the Total Environment. 627: 869-79. https://doi.org/10.1016/j. scitotenv.2018.01.303. 
Bennear, L. S. and R. N. Stavins. 2007. "Second-best Theory and the Use of Multiple Policy Instruments". Environmental and Resource Economics. 37(1): 111-29. https://doi.org/10.1007/s10640-0079110-y.

Bläsing, M. and W. Amelung. 2018. "Plastics in Soil: Analytical Methods and Possible Sources". Science of the Total Environment. 612: 42235. https://doi.org/10.1016/j.scitotenv.2017.08.086.

Boxall, A. B. A. 2012. "New and Emerging Water Pollutants Arising From Agriculture". In: Organisation for Economic Co-Operation and Deveolpment Report.

Bradley, P. M., L. B. Barber, D. W. Kolpin, P. B. McMahon, and F. H. Chapelle. 2008. "Potential for 4-n-Nonylphenol Biodegradation in Stream Sediments". Environmental Toxicology and Chemistry. 27(2): 260-65. https://doi.org/https://doi.org/10.1897/07-333R.1.

Braun, J. M., K. Yolton, K. N. Dietrich, R. Hornung, X. Ye, A. M. Calafat, and B. P. Lanphear. 2009. "Prenatal Bisphenol A Exposure and Early Childhood Behavior". Environmental Health Perspectives. 117(12): 1945-52. https://doi.org/10.1289/ehp.0900979.

Brizga, J., K. Hubacek, and K. Feng. 2020. "The Unintended Side Effects of Bioplastics: Carbon, Land, and Water Footprints". One Earth. 3(1): 45-53. https://doi.org/10.1016/j.oneear.2020.06.016.

Bunke, D., S. Moritz, W. Brack, D. L. Herráez, L. Posthuma, and M. Nuss. 2019. "Developments in Society and Implications for Emerging Pollutants in the Aquatic Environment". Environmental Sciences Europe. 31(1): 32. https://doi.org/10.1186/s12302-019-0213-1.

Caliman, F. A. and M. Gavrilescu. 2009. "Pharmaceuticals, Personal Care Products and Endocrine Disrupting Agents in the Environment - A Review". Clean - Soil, Air, Water. 37(4-5): 277-303. https: //doi.org/10.1002/clen.200900038.

Campo, J., M. Lorenzo, F. Pérez, Y. Picó, M. Farré, and D. Barceló. 2016. "Analysis of the Presence of Perfluoroalkyl Substances in Water, Sediment and Biota of the Jucar River (E Spain). Sources, Partitioning and Relationships with Water Physical Characteristics". Environmental Research. 147: 503-12. https://doi.org/10.1016/j. envres.2016.03.010. 
Castaño-Sánchez, A., G. C. Hose, and A. S. P. S. Reboleira. 2020. "Ecotoxicological Effects of Anthropogenic Stressors in Subterranean Organisms: A Review". Chemosphere: 244. https://doi.org/10.1016/ j.chemosphere.2019.125422.

Ccanccapa, A., A. Masiá, A. Navarro-Ortega, Y. Picó, and D. Barceló. 2016. "Pesticides in the Ebro River Basin: Occurrence and Risk Assessment". Environmental Pollution. 211: 414-24. https://doi.org/ 10.1016/j.envpol.2015.12.059.

CEFIC. 2021. Facts and Figures Report. The European Chemical Industry, A Vital Part of the Europe's Future. https://cefic.org/a-pillarof- the- european- economy / facts- and- figures- of- the- europeanchemical-industry/ accessed 07.01.2021.

da Costa, J. P., P. S. M. Santos, A. C. Duarte, and T. Rocha-Santos. 2016. "(Nano)plastics in the Environment - Sources, Fates and Effects". Science of The Total Environment. 566-567: 15-26. https: //doi.org/10.1016/j.scitotenv.2016.05.041.

de Souza Machado, A. A., W. Kloas, C. Zarfl, S. Hempel, and M. C. Rillig. 2018. "Microplastics as an Emerging Threat to Terrestrial Ecosystems". Global Change Biology. 24(4): 1405-16. https://doi. org/10.1111/gcb.14020.

Deblonde, T., C. Cossu-Leguille, and P. Hartemann. 2011. "Emerging Pollutants in Wastewater: A Review of the Literature". International Journal of Hygiene and Environmental Health. 214(6): 442-48. https: //doi.org/10.1016/j.ijheh.2011.08.002.

"Decision No 2455/2001/EC of the European Parliament and of the Council of 20 November 2001 Establishing the List of Priority Substances in the Field of Water Policy and Amending Directive 2000/60/EC". http://data.europa.eu/eli/dec/2001/2455/oj.

Denver, S., J. D. Jensen, and T. Christensen. 2021. "Consumer Preferences for Reduced Antibiotic use in Danish Pig Production". Preventive Veterinary Medicine. 189(August 2020): 105310. https://doi. org/10.1016/j.prevetmed.2021.105310.

"Directive 2000/60/EC of the European Parliament and of the Council of 23 October 2000 Establishing a Framework for Community Action in the Field of Water Policy". http://data.europa.eu/eli/dir/2000/ $60 / \mathrm{oj}$. 
"Directive 2006/118/EC of the European Parliament and of the Council of 12 December 2006 on the Protection of Groundwater Against Pollution and Deterioration". http://data.europa.eu/eli/dir/2006/ 118/oj.

"Directive 2008/105/EC of the European Parliament and of the Council of 16 December 2008 on Environmental Quality Standards in the Field of Water Policy, Amending and Subsequently Repealing Council Directives 82/176/EEC, 83/513/EEC, 84/156/EEC, 84/491/EEC". http://data.europa.eu/eli/dir/2008/105/oj.

"Directive 2009/128/EC of the European Parliament and of the Council of 21 October 2009 Establishing a Framework for Community Action to Achieve the Sustainable Use of Pesticides". http://data.europa. eu/eli/dir/2009/128/oj.

"Directive 2010/75/EU of the European Parliament and of the Council of 24 November 2010 on Industrial Emissions (Integrated Pollution Prevention and Control)". http://data.europa.eu/eli/dir/2010/75/ oj.

"Directive 2013/39/EU of the European Parliament and of the Council of 12 August 2013 amending Directives 2000/60/EC and 2008/105/EC as Regards Priority Substances in the Field of Water Policy". http: //data.europa.eu/eli/dir/2013/39/oj.

Drewes, J. E., T. Heberer, T. Rauch, and K. Reddersen. 2003. "Fate of Pharmaceuticals During Ground Water Recharge". Groundwater Monitoring 83 Remediation. 23(3): 64-72. https://doi.org/https: //doi.org/10.1111/j.1745-6592.2003.tb00684.x.

Dulio, V., B. van Bavel, E. Brorström-Lundén, J. Harmsen, J. Hollender, M. Schlabach, J. Slobodnik, K. Thomas, and J. Koschorreck. 2018. "Emerging Pollutants in the EU: 10 years of NORMAN in Support of Environmental Policies and Regulations". Environmental Sciences Europe. 30(5). https://doi.org/10.1186/s12302-018-0135-3.

Ebele, A. J., M. A.-E. Abdallah, and S. Harrad. 2017. "Pharmaceuticals and Personal Care Products (PPCPs) in the Freshwater Aquatic Environment". Emerging Contaminants. 3(1): 1-16. https://doi.org/ 10.1016/j.emcon.2016.12.004. 
Ebele, A. J., T. Oluseyi, D. S. Drage, S. Harrad, and M. A.-E. Abdallah. 2020. "Occurrence, Seasonal Variation and Human Exposure to Pharmaceuticals and Personal Care Products in Surface Water, Groundwater and Drinking Water in Lagos State, Nigeria". Emerging Contaminants. 6: 124-32. https://doi.org/10.1016/j.emcon.2020.02. 004 .

European Commission (EC). 2012. "Communication from the Commission to the Council - The Combination Effects of Chemicals. Chemical Mixtures". COM (2012) 252 Final, 10.

Farré, M., S. Pérez, K. Gajda-Schrantz, V. Osorio, L. Kantiani, A. Ginebreda, and D. Barceló. 2010. "First Determination of C60 and C70 Fullerenes and N-methylfulleropyrrolidine C60 on the Suspended Material of Wastewater Effluents by Liquid Chromatography Hybrid Quadrupole Linear Ion Trap Tandem Mass Spectrometry". Journal of Hydrology. 383(1-2): 44-51. https://doi.org/10.1016/j.jhydrol. 2009.08.016.

Fischer, K., K. Sjöström, A. Stiernström, and U. Emanuelson. 2019. "Dairy Farmers' Perspectives on Antibiotic Use: A Qualitative Study". Journal of Dairy Science. 102(3): 2724-37. https:// doi. org/10.3168/jds.2018-15015.

Fisher-Vanden, K. and S. Olmstead. 2013. "Moving Pollution Trading from Air to Water: Potential, Problems, and Prognosis". Journal of Economic Perspectives. 27(1): 147-72. https://doi.org/10.1257/jep. 27.1.147.

Fonseca, E., F. Hernández, M. Ibáñez, A. Rico, E. Pitarch, and L. Bijlsma. 2020. "Occurrence and Ecological Risks of Pharmaceuticals in a Mediterranean River in Eastern Spain". Environment International. 144(April): 106004. https://doi.org/10.1016/j.envint.2020. 106004.

Forti, V., C. P. Baldé, R. Kuehr, and G. Bel. 2020. The Global E-waste Monitor 2020. (Issue July). http://ewastemonitor.info/.

Frade, V. M. F., M. Dias, A. C. S. C. Teixeira, and M. S. A. Palma. 2014. "Environmental Contamination by Fluoroquinolones". Brazilian Journal of Pharmaceutical Sciences. 50(1): 41-54. https://doi. org/10.1590/s1984-82502011000100004. 
Francisco, L. F. V., B. do Amaral Crispim, J. C. V. Spósito, J. C. J. Solórzano, N. H. Maran, F. Kummrow, V. A. do Nascimento, C. C. Montagner, K. M. P. De Oliveira, and A. Barufatti. 2019. "Metals and Emerging Contaminants in Groundwater and Human Health Risk Assessment". Environmental Science and Pollution Research. 26(24): 24581-594. https://doi.org/10.1007/s11356-019-05662-5.

Gavrilescu, M., K. Demnerová, J. Aamand, S. Agathos, and F. Fava. 2015. "Emerging Pollutants in the Environment: Present and Future Challenges in Biomonitoring, Ecological Risks and Bioremediation". New Biotechnology. 32(1): 147-56. https://doi.org/10.1016/j.nbt. 2014.01.001.

Geissen, V., H. Mol, E. Klumpp, G. Umlauf, M. Nadal, M. van der Ploeg, S. E. A. T. M. van de Zee, and C. J. Ritsema. 2015. "Emerging Pollutants in the Environment: A Challenge for Water Resource Management". International Soil and Water Conservation Research. 3(1): 57-65. https://doi.org/10.1016/j.iswcr.2015.03.002.

Geissen, V., F. Q. Ramos, P. de J Bastidas-Bastidas, G. Díaz-González, R. Bello-Mendoza, E. Huerta-Lwanga, and L. E. Ruiz-Suárez. 2010. "Soil and Water Pollution in a Banana Production Region in Tropical Mexico". Bulletin of Environmental Contamination and Toxicology. 85(4): 407-13. https://doi.org/10.1007/s00128-010-0077-y.

Ghermandi, A., J. C. J. M. van den Bergh, L. M. Brander, H. L. F. de Groot, and P. A. L. D. Nunes. 2010. "Values of Natural and Humanmade Wetlands: A Meta-analysis". Water Resources Research. 46(12). https://doi.org/10.1029/2010WR009071.

Göbel, A., C. S. McArdell, A. Joss, H. Siegrist, and W. Giger. 2007. "Fate of Sulfonamides, Macrolides, and Trimethoprim in Different Wastewater Treatment Technologies". Science of the Total Environment. 372(2-3): 361-71. https://doi.org/10.1016/j.scitotenv.2006.07.039.

Goetz, R. U. and A. Xabadia. 2015. "Externalities and Water Quality". In: Handbook of Water Economics and Institutions. Ed. by K. Burnett, R. Howitt, J. Roumasset, and C. Wada. Routledge. 111-33. Gogoi, A., P. Mazumder, V. K. Tyagi, G. G. T. Chaminda, A. K. An, and M. Kumar. 2018. "Occurrence and Fate of Emerging Contaminants in Water Environment: A Review". Groundwater for Sustainable Development. 6(December): 169-80. https://doi.org/10.1016/j.gsd. 2017.12.009. 
González García, M., C. Fernández-López, F. Pedrero-Salcedo, and J. J. Alarcón. 2018. "Absorption of Carbamazepine and Diclofenac in Hydroponically Cultivated Lettuces and Human Health Risk Assessment". Agricultural Water Management. 206: 42-7. https: //doi.org/10.1016/j.agwat.2018.04.018.

Gonzalez Ronquillo, M. and J. C. Angeles Hernandez. 2017. "Antibiotic and Synthetic Growth Promoters in Animal Diets: Review of Impact and Analytical Methods". Food Control. 72: 255-67. https://doi.org/ 10.1016/j.foodcont.2016.03.001.

Grandjean, P. and P. J. Landrigan. 2006. "Developmental Neurotoxicity of Industrial Chemicals". The Lancet. 368(9553): 2167-78. https: //doi.org/10.1016/S0140-6736(06)69665-7.

Grandjean, P. and P. J. Landrigan. 2014. "Neurobehavioural Effects of Developmental Toxicity". The Lancet Neurology. 13(3): 330-38. https://doi.org/10.1016/S1474-4422(13)70278-3.

Griebler, C., F. Malard, and T. Lefébure. 2014. "Current Developments in Groundwater Ecology - From Biodiversity to Ecosystem Function and Services". Current Opinion in Biotechnology. 27: 159-67. https: //doi.org/10.1016/j.copbio.2014.01.018.

Gross, A. and E. Park. 2018. "Water and Wastewater Treatment Worldwide: The Industry and the Market for Equipment and Chemicals". Business Economics. 53(1): 37-47. https://doi.org/10.1057/s11369018-0069-1.

Gurian, P. L., M. J. Small, J. R. Lockwood, and M. J. Schervish. 2004. "Benefit-Cost Implications of Multicontaminant Drinking Waters Tandards". Journal - American Water Works Association. 96(3): 70-83. https://doi.org/10.1002/j.1551-8833.2004.tb10575.x.

Gwenzi, W., L. Mangori, C. Danha, N. Chaukura, N. Dunjana, and E. Sanganyado. 2018. "Sources, Behaviour, and Environmental and Human Health Risks of High-technology Rare Earth Elements as Emerging Contaminants". Science of the Total Environment. 636: 299-313. https://doi.org/10.1016/j.scitotenv.2018.04.235.

Hoel, M. and L. Karp. 2002. "Taxes Versus Quotas for a Stock Pollutant". Resource and Energy Economics. 24(4): 367-84. https://doi.org/10. 1016/S0928-7655(02)00014-3. 
Hurley, R. R. and L. Nizzetto. 2018. "Fate and Occurrence of Micro(nano)plastics in Soils: Knowledge Gaps and Possible Risks". Current Opinion in Environmental Science \& Health. 1: 6-11. https://doi.org/10.1016/j.coesh.2017.10.006.

Iho, A., M. Ribaudo, and K. Hyytiäinen. 2015. "Water Protection in the Baltic Sea and the Chesapeake Bay: Institutions, Policies and Efficiency". Marine Pollution Bulletin. 93(1-2): 81-93. https: //doi.org/10.1016/j.marpolbul.2015.02.011.

Johnson, A. C., M. D. Jürgens, N. Nakada, S. Hanamoto, A. C. Singer, and H. Tanaka. 2017. "Linking Changes in Antibiotic Effluent Concentrations to Flow, Removal and Consumption in Four Different UK Sewage Treatment Plants Over Four Years". Environmental Pollution. 220: 919-26. https://doi.org/10.1016/j.envpol.2016.10.077.

Jones, P. J., J. Sok, R. B. Tranter, I. Blanco-Penedo, N. Fall, C. Fourichon, H. Hogeveen, M. C. Krieger, and A. Sundrum. 2016. "Assessing, and Understanding, European Organic Dairy Farmers' Intentions to Improve Herd Health". Preventive Veterinary Medicine. 133: 84-96. https://doi.org/10.1016/j.prevetmed.2016.08.005.

Kattwinkel, M., J.-V. Kühne, K. Foit, and M. Liess. 2011. "Climate Change, Agricultural Insecticide Exposure, and Risk for Freshwater Communities". Ecological Applications. 21(6): 2068-81. https://doi. org/10.1890/10-1993.1.

Kost, G. J. 2021. "Geospatial Spread of Antimicrobial Resistance, Bacterial and Fungal Threats to Coronavirus Infectious Disease 2019 (COVID-19) Survival, and Point-of-Care Solutions". Archives of Pathology \& Laboratory Medicine. 145(2): 145-67. https://doi.org/ 10.5858/arpa.2020-0284-RA.

Koundouri, P., C. Roseta-Palma, and N. Englezos. 2017. "Out of Sight, Not Out of Mind: Developments in Economic Models of Groundwater Management". International Review of Environmental and Resource Economics. 11(1): 55-96. https://doi.org/10.1561/101.00000091.

Kroon, F. J., K. L. E. Berry, D. L. Brinkman, R. Kookana, F. D. L. Leusch, S. D. Melvin, P. A. Neale, A. P. Negri, M. Puotinen, J. J. Tsang, J. P. van de Merwe, and M. Williams. 2020. "Sources, Presence and Potential Effects of Contaminants of Emerging Concern in the Marine Environments of the Great Barrier Reef and Torres Strait, Australia". Science of the Total Environment. 719: 135140. https: //doi.org/10.1016/j.scitotenv.2019.135140. 
Lai, W. 2017. "Pesticide Use and Health Outcomes: Evidence from Agricultural Water Pollution in China". Journal of Environmental Economics and Management. 86: 93-120. https://doi.org/10.1016/j. jeem.2017.05.006.

Landrigan, P. J., R. Fuller, N. J. R. Acosta, O. Adeyi, R. Arnold, N. (Nil) Basu, A. B. Baldé, R. Bertollini, S. Bose-O'Reilly, J. I. Boufford, P. N. Breysse, T. Chiles, C. Mahidol, A. M. Coll-Seck, M. L. Cropper, J. Fobil, V. Fuster, M. Greenstone, A. Haines, et al. 2018. "The Lancet Commission on Pollution and Health". The Lancet. 391(10119): 462 512. https://doi.org/10.1016/S0140-6736(17)32345-0.

Lankoski, J., E. Lichtenberg, and M. Ollikainen. 2008. "Point/Nonpoint Effluent Trading with Spatial Heterogeneity". American Journal of Agricultural Economics. 90(4): 1044-58. https://doi.org/10.1111/j. 1467-8276.2008.01172.x.

Lapworth, D. J., N. Baran, M. E. Stuart, and R. S. Ward. 2012. "Emerging Organic Contaminants in Groundwater: A Review of Sources, Fate and Occurrence". Environmental Pollution. 163: 287-303. https: //doi.org/10.1016/j.envpol.2011.12.034.

Lei, M., L. Zhang, J. Lei, L. Zong, J. Li, Z. Wu, and Z. Wang. 2015. "Overview of Emerging Contaminants and Associated Human Health Effects". BioMed Research International. 2015: 404796. https://doi. org/10.1155/2015/404796.

Lekagul, A., V. Tangcharoensathien, and S. Yeung. 2019. "Patterns of Antibiotic Use in Global Pig Production: A Systematic Review". Veterinary and Animal Science. 7(March): 100058. https://doi.org/ $10.1016 /$ j.vas.2019.100058.

Lipsey, R. G. and K. Lancaster. 1956. "The General Theory of Second Best". The Review of Economic Studies. 24(1): 11. https://doi.org/ $10.2307 / 2296233$.

Liu, W. J., R. Zou, Y. Hu, M. Zhao, C. Quan, S. Tan, K. Luo, J. Yuan, H. Zheng, J. Liu, M. Liu, Y. Bi, J. Yan, B. Zhu, B. D. Wang, G. Wu, L. Liu, K.-Y. Yuen, G. F. Gao, and Y. Liu. 2018. "Clinical, Immunological and Bacteriological Characteristics of H7N9 Patients Nosocomially Co-infected by Acinetobacter Baumannii: A Case Control Study". BMC Infectious Diseases. 18(1): 664. https: //doi.org/10.1186/s12879-018-3447-4. 
Luo, Y., W. Guo, H. H. Ngo, L. D. Nghiem, F. I. Hai, J. Zhang, S. Liang, and X. C. Wang. 2014. "A Review on the Occurrence of Micropollutants in the Aquatic Environment and their Fate and Removal During Wastewater Treatment". Science of the Total Environment. 473-474: 619-41. https://doi.org/10.1016/j.scitotenv.2013.12.065.

Margot, J., C. Kienle, A. Magnet, M. Weil, L. Rossi, L. F. de Alencastro, C. Abegglen, D. Thonney, N. Chèvre, M. Schärer, and D. A. Barry. 2013. "Treatment of Micropollutants in Municipal Wastewater: Ozone or Powdered Activated Carbon?" Science of the Total Environment. 461-462: 480-98. https://doi.org/10.1016/j.scitotenv. 2013.05.034.

Marí, A. I., G. Pardo, A. Cirujeda, and Y. Martínez. 2019. "Economic Evaluation of Biodegradable Plastic Films and Paper Mulches used in Open-air Grown Pepper (Capsicum annum 1.) Crop". Agronomy. 9(1). https://doi.org/10.3390/agronomy9010036.

Martín-López, B., E. Gómez-Baggethun, M. García-Llorente, and C. Montes. 2014. "Trade-offs Aross Value-domains in Ecosystem Services Assessment". Ecological Indicators. 37: 220-28. https://doi. org/10.1016/j.ecolind.2013.03.003.

Miles, C., L. DeVetter, S. Ghimire, and D. G. Hayes. 2017. "Suitability of Biodegradable Plastic Mulches for Organic and Sustainable Agricultural Production Systems". HortScience. 52(1): 10-15. https: //doi.org/10.21273/HORTSCI11249-16.

Miranda, C., V. Silva, R. Capita, C. Alonso-Calleja, G. Igrejas, and P. Poeta. 2020. "Implications of Antibiotics Use During the COVID-19 Pandemic: Present and Future". Journal of Antimicrobial Chemotherapy. 75(12): 3413-16. https://doi.org/10.1093/jac/dkaa350.

Mohapatra, D. P. and D. M. Kirpalani. 2019. "Advancement in Treatment of Wastewater: Fate of Emerging Contaminants". Canadian Journal of Chemical Engineering. 97(10): 2621-31. https://doi.org/ 10.1002 / cjce.23533.

Molinos-Senante, M., R. Reif, M. Garrido-Baserba, F. HernándezSancho, F. Omil, M. Poch, and R. Sala-Garrido. 2013. "Economic Valuation of Environmental Benefits of Removing Pharmaceutical and Personal Care Products from WWTP Effluents by Ozonation". Science of The Total Environment. 461-462: 409-15. https: //doi.org/10.1016/j.scitotenv.2013.05.009. 
Mund, M. D., U. H. Khan, U. Tahir, B.-E. Mustafa, and A. Fayyaz. 2017. "Antimicrobial Drug Residues in Poultry Products and Implications on Public Health: A Review". International Journal of Food Properties. 20(7): 1433-46. https://doi.org/10.1080/10942912.2016. 1212874.

Noguera-Oviedo, K. and D. S. Aga. 2016. "Lessons Learned from More Than Two Decades of Research on Emerging Contaminants in the Environment". Journal of Hazardous Materials. 316: 242-51. https: //doi.org/10.1016/j.jhazmat.2016.04.058.

Pal, A., K. Y. H. Gin, A. Y. C. Lin, and M. Reinhard. 2010. "Impacts of Emerging Organic Contaminants on Freshwater Resources: Review of Recent Occurrences, Sources, Fate and Effects". Science of the Total Environment. 408(24): 6062-69. https://doi.org/10.1016/j. scitotenv.2010.09.026.

Pardo, G. and Y. Martínez. 2019. "Conservation Agriculture in Trouble? Estimating the Economic Impact of an Eventual Glyphosate Prohibition in Spain". Planta Daninha: 37. https://doi.org/10.1590/s010083582019370100138.

Payá Pérez, A. and N. R. Eugenio. 2018. Status of Local Soil Contamination in Europe - Revision of the Indicator "Progress in the Management Contaminated Sites in Europe". EUR 29124 EN, Publications Office of the European Union, Luxembourg. https: //doi.org/10.2760/093804.

Pearce, D. and P. Koundouri. 2003a. "Chemicals and Health". In: The Social Cost of Chemicals: The Cost and Benefits of Future Chemicals Policy in the European Union. A Report for WWF-UK.

Pearce, D. and P. Koundouri. 2003b. "Diffusion Pollution and the Role of Agriculture". In: Water Sustainability and Regulation: The Next Periodic Review and Beyond. Ed. by D. Helm. OXERA Press. 12553.

Peña-Guzmán, C., S. Ulloa-Sánchez, K. Mora, R. Helena-Bustos, E. Lopez-Barrera, J. Alvarez, and M. Rodriguez-Pinzón. 2019. "Emerging Pollutants in the Urban Water Cycle in Latin America: A Review of the Current Literature". Journal of Environmental Management. 237(December 2018): 408-23. https://doi.org/10.1016/j.jenvman. 2019.02.100. 
Perry, E. D. and G. C. Moschini. 2020. "Neonicotinoids in U.S. Maize: Insecticide Substitution Effects and Environmental Risk". Journal of Environmental Economics and Management. 102: 102320. https: //doi.org/10.1016/j.jeem.2020.102320.

Petrie, B., R. Barden, and B. Kasprzyk-Hordern. 2015. "A Review on Emerging Contaminants in Wastewaters and the Environment: Current Knowledge, Understudied Areas and Recommendations for Future Monitoring". Water Research. 72: 3-27. https://doi.org/10. 1016/j.watres.2014.08.053.

Petrović, M., S. Gonzalez, and D. Barceló. 2003. "Analysis and Removal of Emerging Contaminants in Wastewater and Drinking Water". TrAC - Trends in Analytical Chemistry. 22(10): 685-96. https: //doi.org/10.1016/S0165-9936(03)01105-1.

Pistocchi, A., A. Aloe, C. Dorati, L. Alcalde Sanz, F. Bouraoui, B. Gawlik, B. Grizzetti, M. Pastori, and O. Vigiak. 2017. The potential of water reuse for agricultural irrigation in the EU. A Hydro-Economic Analysis, EUR 28980 EN, Publications Office of the European Union, Luxembourg, 2018. ISBN 978-92-79-77210-8, doi:10.2760/263713, JRC109870.

Raboisson, D., A. Ferchiou, P. Sans, G. Lhermie, and M. Dervillé. 2020. "The Economics of Antimicrobial Resistance in Veterinary Medicine: Optimizing Societal Benefits through Mesoeconomic Approaches from Public and Private Perspectives". One Health. 10: 100145. https://doi.org/10.1016/j.onehlt.2020.100145.

Rawson, T. M., L. S. P. Moore, N. Zhu, N. Ranganathan, K. Skolimowska, M. Gilchrist, G. Satta, G. Cooke, and A. Holmes. 2020. "Bacterial and Fungal Coinfection in Individuals With Coronavirus: A Rapid Review To Support COVID-19 Antimicrobial Prescribing". Clinical Infectious Diseases. 71(9): 2459-68. https://doi.org/10.1093/cid/ciaa530.

Re, V. 2019. "Shedding Light on the Invisible: Addressing the Potential for Groundwater Contamination by Plastic Microfibers". Hydrogeology Journal. 27(7): 2719-27. https://doi.org/10.1007/s10040-01901998-x. 
"Regulation (EC) No 166/2006 of the European Parliament and of the Council of 18 January 2006 concerning the establishment of a European Pollutant Release and Transfer Register and amending Council Directives 91/689/EEC and 96/61/EC". http://data.europa. $\mathrm{eu} / \mathrm{eli} / \mathrm{reg} / 2006 / 166 / \mathrm{oj}$.

"Regulation (EC) No 1907/2006 of the European Parliament and of the Council of 18 December 2006 concerning the Registration, Evaluation, Authorisation and Restriction of Chemicals (REACH), Establishing a European Chemicals Agency, Amending Directive 1999/4". http://data.europa.eu/eli/reg/2006/1907/2014-04-10.

"Regulation (EU) 2019/4 of the European Parliament and of the Council of 11 December 2018 on the Manufacture, Placing on the Market and Use of Medicated Feed, Amending Regulation (EC) No 183/2005 of the European Parliament and of the Council and Repealing". http://data.europa.eu/eli/reg/2019/4/oj.

"Regulation (EU) 2019/6 of the European Parliament and of the Council of 11 December 2018 on Veterinary Medicinal Products and Repealing Directive 2001/82/EC". http://data.europa.eu/eli/reg/2019/6/ oj.

Remoundou, K. and P. Koundouri. 2009. "Environmental Effects on Public Health: An Economic Perspective". International Journal of Environmental Research and Public Health. 6(8): 2160-78. https: //doi.org/10.3390/ijerph6082160.

Robertson, J., V. Vlahović-Palčevski, K. Iwamoto, L. D. Högberg, B. Godman, D. L. Monnet, S. Garner, and K. Weist. 2021. "Variations in the Consumption of Antimicrobial Medicines in the European Region, 2014-2018: Findings and Implications from ESAC-Net and WHO Europe". Frontiers in Pharmacology. 12(June): 1-14. https: //doi.org/10.3389/fphar.2021.639207.

Rodriguez-Mozaz, S., I. Vaz-Moreira, S. Varela Della Giustina, M. Llorca, D. Barceló, S. Schubert, T. U. Berendonk, I. Michael-Kordatou, D. Fatta-Kassinos, J. L. Martinez, C. Elpers, I. Henriques, T. Jaeger, T. Schwartz, E. Paulshus, K. O'Sullivan, K. M. M. Pärnänen, M. Virta, T. T. Do, et al. 2020. "Antibiotic Residues in Final Effluents of European Wastewater Treatment Plants and their Impact on the Aquatic Environment". Environment International. 140(March): 105733. https://doi.org/10.1016/j.envint.2020.105733. 
Roope, L. S. J., R. D. Smith, K. B. Pouwels, J. Buchanan, L. Abel, P. Eibich, C. C. Butler, P. S. Tan, A. S. Walker, J. V. Robotham, and S. Wordsworth. 2019. "The Challenge of Antimicrobial Resistance: What Economics Can Contribute". Science. 364(6435): eaau4679. https://doi.org/10.1126/science.aau4679.

Sathishkumar, P., R. A. A. Meena, T. Palanisami, V. Ashokkumar, T. Palvannan, and F. L. Gu. 2020. "Occurrence, Interactive Effects and Ecological Risk of Diclofenac in Environmental Compartments and Biota - A Review". Science of the Total Environment. 698: 134057. https://doi.org/10.1016/j.scitotenv.2019.134057.

Sauvé, S. and M. Desrosiers. 2014. "A Review of What is an Emerging Contaminant". Chemistry Central Journal. 8(1): 1-7. https://doi. org/10.1186/1752-153X-8-15.

Scheidleder, A. 2012. Groundwater Threshold Values: In-Depth Assessment of the Differences in Groundwater Threshold Values Established by Member States. AustriaUmweltbundesamt (Environment Agency Austria): Vienna, Austria, 57. https://doi.org/10.13140/2.1.2305. 6164 .

Schiedek, D., B. Sundelin, J. W. Readman, and R. W. Macdonald. 2007. "Interactions between Climate Change and Contaminants". Marine Pollution Bulletin. 54(12): 1845-56. https://doi.org/10.1016/j. marpolbul.2007.09.020.

Schwarzenbach, R. P., B. I. Escher, K. Fenner, T. B. Hofstetter, C. A. Johnson, U. von Gunten, and B. Wehrli. 2006. "The Challenge of Micropollutants in Aquatic Systems". Science. 313(5790): 1072-77. https://doi.org/10.1126/science.1127291.

Seeberger, J., R. Grandhi, S. S. Kim, W. A. Mase, T. Reponen, S. Ho, and A. Chen. 2016. "Special Report: E-Waste Management in the United States and Public Health Implications". Journal of Environmental Health. 79(3): 8-16.

Sexton, S. S., Z. Lei, and D. Zilberman. 2007. "The Economics of Pesticides and Pest Control". International Review of Environmental and Resource Economics. 1(3): 271-326. https://doi.org/10.1561/ 101.00000007.

Shortle, J. 2017. "Policy Nook: 'Economic Incentives for Water Quality Protection". Water Economics and Policy. 03(02): 1771004. https: //doi.org/10.1142/S2382624X17710047. 
Shortle, J. and R. D. Horan. 2013. "Policy Instruments for Water Quality Protection". Annual Review of Resource Economics. 5(1): 111-38. https://doi.org/10.1146/annurev-resource-091912-151903.

Shortle, J. and R. D. Horan. 2017. "Nutrient Pollution: A Wicked Challenge for Economic Instruments". Water Economics and Policy. 03(02): 1650033. https://doi.org/10.1142/s2382624x16500338.

Sinclair, C. J. and A. B. A. Boxall. 2003. "Assessing the Ecotoxicity of Pesticide Transformation Products". Environmental Science and Technology. 37(20): 4617-25. https://doi.org/10.1021/es030038m.

Snow, D. D., D. A. Cassada, S. Biswas, A. Malakar, M. D'Alessio, L. J. Carter, R. D. Johnson, and J. B. Sallach. 2019. "Detection, Occurrence, and Fate of Emerging Contaminants in Agricultural Environments". Water Environment Research. 91(10): 1103-13. https: //doi.org/10.1002/wer.1204.

Stefanakis, A. I. and J. A. Becker. 2015. "A Review of Emerging Contaminants in Water: Classification, Sources, and Potential Risks". In: Impact of Water Pollution on Human Health and Environmental Sustainability. Ed. by by E. McKeown and G. Bugyi. https: //doi.org/10.4018/978-1-4666-9559-7.ch003. IGI Global. 55-80.

Stuart, M. E., K. Manamsa, J. C. Talbot, and E. J. Crane. 2011. "Emerging Contaminants in Groundwater". British Geological Survey, Open Report OR/11/013: 1-111.

Stuart, M., D. Lapworth, E. Crane, and A. Hart. 2012. "Review of Risk from Potential Emerging Contaminants in UK Groundwater". Science of The Total Environment. 416: 1-21. https://doi.org/10. 1016/j.scitotenv.2011.11.072.

Thompson, C., R. Sweitzer, M. Gabriel, K. Purcell, R. Barrett, and R. Poppenga. 2014. "Impacts of Rodenticide and Insecticide Toxicants from Marijuana Cultivation Sites on Fisher Survival Rates in the Sierra National Forest, California". Conservation Letters. 7(2): 91102. https://doi.org/10.1111/conl.12038.

Topp, E., J. G. Hendel, D. R. Lapen, and R. Chapman. 2008. "Fate of the Nonsteroidal Anti-inflammatory Drug Naproxen in Agricultural Soil Receiving Liquid Municipal Biosolids". Environmental Toxicology and Chemistry. 27(10): 2005. https://doi.org/10.1897/07-644.1. 
Torres-Padrón, M. E., S. Montesdeoca-Esponda, S. Santana-Viera, R. Guedes-Alonso, J. A. Herrera-Melián, Z. Sosa-Ferrera, and J. J. Santana-Rodríguez. 2020. "An Update of the Occurrence of Organic Contaminants of Emerging Concern in the Canary Islands (Spain)". Water. 12(9): 2548. https://doi.org/10.3390/w12092548.

Vasilachi, I., D. Asiminicesei, D. Fertu, and M. Gavrilescu. 2021. "Occurrence and Fate of Emerging Pollutants in Water Environment and Options for Their Removal". Water. 13(2): 181. https://doi.org/10. $3390 /$ w13020181.

Voulvoulis, N. 2018. "Water Reuse from a Circular Economy Perspective and Potential Risks from an Unregulated Approach". Current Opinion in Environmental Science and Health. 2: 32-45. https: //doi.org/10.1016/j.coesh.2018.01.005.

Ward, J., S. P. Mohapatra, and A. Mitchell. 2008. "An Overview of Policies for Managing Polybrominated Diphenyl Ethers (PBDEs) in the Great Lakes Basin". Environment International. 34(8): 1148-56. https://doi.org/10.1016/j.envint.2008.05.003.

Warren, G. S. 2015. "Regulating Pot to Save the Polar Bear: Energy and Climate Impacts of the Marijuana Industry". Columbia Journal of Environmental Law. 40: 385-432. https://doi.org/10.7916/cjel. v40i3.3541.

Westling, N., P. M. Stromberg, and R. B. Swain. 2020. "Can Upstream Ecosystems Ensure Safe Drinking Water - Insights from Sweden". Ecological Economics. 169(November 2019): 106552. https://doi. org/10.1016/j.ecolecon.2019.106552.

Whitehead, P. G., R. L. Wilby, R. W. Battarbee, M. Kernan, and A. J. Wade. 2009. "A Review of the Potential Impacts of Climate Change on Surface Water Quality". Hydrological Sciences Journal. 54(1): 101-23. https://doi.org/10.1623/hysj.54.1.101.

Workgroup on Emerging Contaminants, U. S. E. P. A. 2008. White paper. Aquatic life criteria for contaminants of emerging concern. Part I: General challenges and recommendations.

Wu, X., X. Lyu, Z. Li, B. Gao, X. Zeng, J. Wu, and Y. Sun. 2020. "Transport of Polystyrene Nanoplastics in Natural Soils: Effect of Soil Properties, Ionic Strength and Cation Type". Science of the Total Environment. 707: 136065. https://doi.org/10.1016/j.scitotenv. 2019.136065. 
Xu, H., G. Lu, and C. Xue. 2020. "Effects of Sulfamethoxazole and 2Ethylhexyl-4-methoxycinnamate on the Dissimilatory Nitrate Reduction Processes and $\mathrm{N}_{2} \mathrm{O}$ Release in Sediments in the Yarlung Zangbo River". International Journal of Environmental Research and Public Health. 17(6). https://doi.org/10.3390/ijerph17061822.

Zhou, P., Z. Liu, Y. Chen, Y. Xiao, X. Huang, and X.-G. Fan. 2020. "Bacterial and Fungal Infections in COVID-19 Patients: A Matter of Concern". Infection Control \& Hospital Epidemiology. 41(9): 112425. https://doi.org/10.1017/ice.2020.156. 